\title{
First RECORDS OF STRANDED PREgNANT FEMALE SOUTH AMERICAN FUR SEALS, ARCTOCEPHALUS AUSTRALIS, IN THE SOUTHERN BRAZILIAN COAST
}

\author{
Mônica Mathias Costa Muelbert ${ }^{1}$ and Larissa Rosa de Oliveira ${ }^{2,3,4}$
}

There are no breeding colonies of pinnipeds along the Brazilian coast. Nevertheless, every year the occurrence of many specimens of sea lions, fur seals, elephant seals and even Antarctic seals, along the Brazilian coast is very common (Simões-Lopes et al., 1995; Oliveira et al., 2001) especially during the austral autumn and spring months. These occurrences happen mainly along the coast of the Rio Grande do Sul state and are a result of the dispersion of individuals from their natal colonies after the breeding period when they begin to forage. It has been suggested that these movements are influenced by the cold Malvinas (Falkland) Current (Pinedo, 1990). In spite of the absence of breeding colonies in Brazil, there are two areas where otariids haul-out: the Wildlife Reserve of the eastern jetty of the Lagoa dos Patos (REVIS Molhe Leste - 32 $12^{\prime} S$; $52^{\circ} 06^{\prime} \mathrm{W}$ ) and the Wildlife Reserve of Ilha dos Lobos, Torres (REVIS Ilha dos Lobos -29 20'S; 49 43’W) (Vaz-Ferreira, 1982; Rosas et al., 1994). The most frequent species of pinnipeds in the area are the South American fur seal, Arctocephalus australis, and the South American sea lion (Otaria flavescens) (SimõesLopes et al., 1995; Oliveira, 1999). Pinedo (1986, 1990), Rosas (1989); Rosas et al. (1994) and Oliveira (1999) provided a detailed description of the occurrence of pinnipeds along the southern Brazilian coast. After these studies, it is well accepted that sea lions and fur seals rest in the southern Brazilian coast during their northward foraging trips after their depart from breeding colonies in Uruguay where there are rookeries at Cabo Polonio $(250 \mathrm{~km}$ south of the Eastern jetty of Lagoa dos Patos) and Isla de Lobos (Punta del Este, Uruguay) ( $450 \mathrm{~km}$ south of the Eastern jetty). The pattern of occurrence of pinnipeds along the Brazilian coast was first described by Pinedo (1990). Both Pinedo (1986) and Oliveira (1999) provided accurate accounts of the occurrence of $A$. australis in Brazil according to data from beach surveys of stranded (live and dead) individuals. According to these studies the predominant age classes found were yearlings of both sexes and adult males. Just few adult females were recorded and up to now there is poor information about adult females' dispersal movements. There had been no published record of pregnant females to date. Thus, here we present the first records of the occurrence of stranded pregnant female South American fur seals in the southern Brazilian coast. We also discuss the implications of these occurrences in light of the present knowledge of post-breeding movements of the species. During systematic beach surveys conducted by the Marine Mammal Laboratory (LMM-D.Oc.) at Fundação Universidade Federal do Rio Grande (Rio Grande) Brazil from 1976 to 2001, 340 specimens of $A$. australis were collected (156 males, 96 females and 85 unknown). These surveys took place along the southern coast of Rio Grande do Sul State (between $30^{\circ}$ and $31^{\circ} \mathrm{S}$ ). During this time, four pregnant female South American fur seals, and their respective fetuses were collected and placed in the collection of the LMM. These females represented 1.5\% of the sexed individuals $(n=255)$ and $4.2 \%$ of all females collected $(n=96)$. Osteological material was deposited into the LMM-D.Oc. collection under the numbers: LMM740, LMM742, LMM1110, and LMM2039. The fetuses received the same number as their mothers with the addition of the letter " $a$ ". As the occurrence of A. australis along the Brazilian coast was represented mostly by yearlings from both sexes and adult males, it has been suggested that the lack of adult females in this area would reflect the fact that females would have limited swimming skills and/or would be staying with their pups in the Uruguayan breeding colonies during austral winter months (Pinedo, 1986, 1990; Oliveira, 1999). However, female dispersal of about $350 \mathrm{~km}$ has been reported for other otariid species (Boyd et al., 1998; Lea et al., 2002; A.R. Martin, pers. comm. ${ }^{5}$. Lactating fur seal females are reported to travel long distances away from their original breeding colonies during the lactation period (Georges and Guinet, 2000; Georges et al., 2000). Thus, the presence of pregnant females in southern Brazil suggest that females are able to swim longer distances $(>250 \mathrm{~km})$ than earlier anticipated; and/or that not all females stay close to their original colonies after the breeding period. This could also suggest that these females were no longer nursing, and/or did not have a pup during the previous year; and/or that they died far away from the coast but reached shore due to the influence of coastal marine currents.

\footnotetext{
${ }^{1}$ Fundação Universidade Federal do Rio Grande, Programa de Pós Graduação em Oceanografia Biológica, Laboratório de Mamíferos Marinhos e Tartarugas Marinhas. Caixa. Postal 474, Rio Grande RS 96201-900 Brasil. E-mail: mamiferos@furg.br.

${ }^{2}$ Grupo de Estudos de Mamíferos Aquáticos do Rio Grande do Sul (GEMARS). Rua Felipe Neri, 382/203, Porto Alegre RS $90440-150$ Brazil. E-mail: lari_minuano@yahoo.com.br.

${ }^{3}$ Centro de Estudos Costeiros, Limnológicos e Marinhos (CECLIMAR) \& Universidade Federal do Rio Grande do Sul (UFRGS). Av. Tramandaí, 976, Imbé RS Brazil

${ }^{4}$ Centro de Biologia Genômica e Molecular da Pontifícia Universidade Católica do Rio Grande do Sul (PUCRS), Faculdade de Biociências. Av. Ipiranga, 6681, Prédio 12A, Porto Alegre RS 90619-900 Brazil.

${ }^{5}$ Antony R. Martin, British Antarctic Survey, Natural Environment Research Council, High Cross, Madingley Road, Cambridge, CB3 OET, United Kingdom.
} 
It is known that otariid females tend to stay close to the breeding colonies while nursing their pups (Gentry and Kooyman, 1986). Boyd et al. (1998) reported the movements of satellite linked time-depth-recorder (STDR) attached to male and female of Antarctic fur seals, Arctocephalus gazella, at Bird Island, South Georgia such that during the post-breeding period males traveled around $886 \mathrm{~km}$ while foraging towards Signy Islands, South Orkneys while females fed closer (350km) to their reproductive colony. The authors believe that the need to return to feed their dependent pups obligates the females to forage close to the colony. Sub-Antarctic fur seals, A. tropicalis also tend to forage further from their colonies in winter months (up to $530 \mathrm{~km}$ ) when the Sub-Tropical Front migrates further north of Amsterdam Island (Georges et al., 2000). If we consider, after Ponce de León (1983), that South American fur seal pups are born by late November-early December; that there is a three month delayed implantation period; that the embryo begins to develop by early March; and, that the month of August would be the peak of weaning period; then, we can speculate that September would correspond roughly to the sixth month of pre-natal development. In this case, the fetuses reported herein would have been approximately six, seven and eight months of pre-natal development, respectively, which would suggest that their mothers would have been in the middle or end of the gestation period. Furthermore, it is likely that these females had already weaned their pups and were starting the pelagic phase of their life cycle when moving northwards in search of food. The information presented here, though scanty and representing only a small proportion of the total number of females breeding in Uruguayan colonies, does indicate that some pregnant females could be moving northwards several hundreds kilometers to forage. Thus, it reinforces the importance of long term monitoring studies to improve our knowledge of the post-breeding dispersion patterns of southern otariids. In addition, the assessment of the relative importance of southern Brazilian coast as a feeding ground for the South American fur seals deserves future research.

\section{Acknowledgments}

We thank Maria Cristina Pinedo for the effort of putting together and maintaining the osteological collection from the Marine Mammal Laboratory at Fundação Universidade Federal do Rio Grande (LMM-D.Oc.FURG), Rio Grande, Brazil from 1976 to 2001. Monitoring of the southern Brazilian coast by the LMMD.Oc. was made possible by grants of several funding agencies throughout the years: CNPq, CAPES and Yaqu Pacha Foundation. M.M.C. Muelbert is supported by a grant from CAPES and L.R. Oliveira was supported by grants from FAPESP (00/00248-2 and 00/01340-0), Society for Marine Mammalogy (grants-in-aid program) and CNPq (151307/2005-9).

\section{References}

Boyd, I.L., Mc CAFFerty, D.J., ReID, TAYLOR, R.K. AND WalKer, T.R. (1998) Dispersal of male and female Antarctic fur seal (Arctocephalus gazella). Canadian Journal of Fisheries and Aquatic Science 55: 845-852.

Gentry, R. And Kooyman, G. (1986) Fur seals: Maternal strategies on land and at sea. Princeton University Press. Princeton, New Jersey, USA. 309 pp.

Georges, J.-Y. And Guinet, C. (2000) Maternal care in the subantarctic fur seals on Amsterdam Island. Ecology 81: 295-308.

Georges, J.-Y., Bonadonna, F. And Guinet, C. (2000) Foraging habitat and diving activity of lactating Subantarctic fur seals in relation to sea-surface temperatures at Amsterdam Island. Marine Ecology Progress Series 196: 279-290.

Lea, M., Hindell, M., Guinet, C. And Goldsworthy, S. (2002) Variability in the diving activity of Antarctic fur seals, Arctocephalus gazella, at Iles Kerguelen. Polar Biology 25: 269-279.

OLIVEIRA, L.R. (1999) Caracterização dos padrões de ocorrência dos pinídepes (Carnivora: Pinnipedia) ocorrentes no litoral do Rio Grande do Sul, Brasil, entre 1993 e 1999. M.Sc. Thesis. Pontifícia Universidade Católica do Rio Grande do Sul. Porto Alegre, RS, Brazil. 154 pp.

Oliveira, L.R., Danilewicz, D., Martins, M.B., Ott, P., Moreno, I.B. AND CAON, G. (2001) New records of the Antarctic fur seal, Arctocephalus gazella (Peters, 1875) to the Brazilian coast. Comunicações do Museu de Ciências e Tecnologia da PUCRS, Série Zoologia 14: 201-207.

PINEDO, M.C. (1986) Mortalidade de Pontoporia blainvillei, Tursiops gephyreus, Otaria flavescens e Arctocephalus australis na costa do Rio Grande do Sul, Brasil, 1976-1983. Pages 187-199 in Actas, I Reunión de Trabajo de Expertos en Mamíferos Acuáticos de América del Sur, 25-29 June. Buenos Aires, Argentina.

Pinedo, M.C. (1990) Ocorrência de Pinípedes na costa brasileira. Garcia de Orta, Série Zoologia, 15(2): 37-48.

Ponce de Léon, A. (1983) Aspectos de la reproducción, crecimento intrauterino y desarollo postnatal del lobo de dos pelos sudamericano Arctocephalus australis (Zimmermann, 1783) en islas de la República Oriental del Uruguay. Ph.D. Thesis Universidad de la República. Montevideo, Uruguay. 93 pp.

Rosas, F.C.W., Pinedo, M.C., Marmontel, M. and Haimovici, M. (1994) Seasonal movements of the South American sea lion (Otaria flavescens, Shaw) off the Rio Grande do Sul coast, Brazil. Mammalia 58: 51-59.

Simões-Lopes, P.C., Drehmer, C.J. And Ott, P.H. (1995) Nota sobre os Otariidae e Phocidae (Mammalia: Carnivora) da costa norte do Rio Grande do Sul e Santa Catarina, Brasil. Biociências 3(1): 173-181.

Vaz-Ferreira, R. (1982) Otaria flavescens (Shaw) South American sea lion. Pages 477-495 in FOOD AND Agriculture Organization. Mammals in the seas: Small cetaceans, seals, sirenians and otters. FAO Fisheries Series 5, Rome: United Nations. 531pp.

Received 20 April 2005. Accepted 21 January 2006. 